\title{
The Influence of Web Adverts on Student Decision-Making Process for University Enrollments
}

\author{
Gautam S. Bapat, Nishu Ayedee, Ravikumar M. Chitnis
}

\begin{abstract}
Universities across the world became digital because of this epidemic. One of the areas that went nearly entirely digital was the annual process of student enrolling. During this period, all the old methods of web advertising were put to the test. In this case, the researcher was compelled to analyze the aspects that were significant to students' enrollment decisions based on his field experience. Experimental research was done to examine the impact web ads have on pupils and parents. The goal of this study was to find admissions for the academic year 2020-21 in India. The poll included close to a thousand students who were recently admitted to the university. The results of the study revealed that web advertisements had a detrimental impact on pupils of all ages, while they had an equal impact on rural and urban candidates. Furthermore, the candidate's family history had little bearing on the impact of web advertisements.
\end{abstract}

Keywords: University Enrollments; Web Adverts; Pandemic, India, Digital Marketing.

JEL Classification: M370, M150, M300, M310

\section{Introduction}

Many academics have said that the internet is one such media that has the most influence on students' admissions decisions (Herold et al., 2017; Humlum et al., 2017; Keegan \& Rowley, 2017; Kusumavati, 2019). When limiting the definition of the term internet, almost all of the researchers referred to all of the current social media sites (Gottlieb \& Beatson, 2018; Joshi et al., 2017; Keegan \& Rowley, 2017; Kozinets, 1999). It was also widely noticed that, in order to access the thoughts of potential candidates, all higher educational institutions now use web advertisements as an important element of their marketing campaigns and promotional programmes (G. S. Bapat et al., 2021).

In the last two decades, advertisements on the internet have garnered a lot of attention and acceptance (Jan \& Ammari, 2016; Mohammed \& Alkubise, 2012; Schlosser et al., 1999). The Internet is used to create a variety of advertising to reach the target demographic. The Internet is recognised for providing marketers with some unique possibilities as well as problems. Internet advertising allows you to communicate commercial information in a variety of ways (Aydoğan et al., 2016). The format of online commercials is both similar and distinct to traditional advertisement formats such as billboards and banner adverts (Aydoğan et al., 2016; Duffett, 2017; Kumar et al., 2021; Taken Smith, 2012).

The way advertisers, ad agencies, media, and consumers engage has also changed as a result of the Internet (Mittal, 2017; Nicosia, 1966). The exponential rise of internet advertising over the previous two decades demonstrates that it is a viable alternative to traditional communication. At the same time, internet advertising has demonstrated that to benefit from this medium, marketers and advertisers must have a thorough grasp of how their target audience

\footnotetext{
Dr. Gautam S. Bapat, Vishwanath Karad, MIT World Peace University, Pune, India, e-mail: gautam.bapat@mitwpu.edu.in Dr. Nishu Ayedee, Marketing \& Promotions, Kingdom of Dreams, Sector 29, Gurgaon, India

Dr. Ravikumar M. Chitnis, MIT World Peace University, Pune, India
} 
interacts with it (Winn et al., 2014).

\subsection{Purpose of the Article}

Almost all higher education institutions were driven to adjust too soon to this worldwide pandemic (G. Bapat et al., 2021; Coyne et al., 2020). All higher education institutions throughout the world were forced to lock their doors and cease all research and teaching activities on their campuses (Coyne et al., 2020; Usher et al., 2020). It was observed, practically all higher educational institutions were able to cope with the disturbance and somehow managed to go by it. They also presented academics in a web-based format. Almost all higher education institutions used the internet for their examinations and evaluations. The most significant problem they all faced was reaching out to potential candidates for the academic year 2020-21 enrollments. (Le et al., 2020). The most noticeable difference in the entrance season of academic year 2020-21 was that all possible candidates were placed under lockdown and were unable to access the campus to get a feel for it and experience it for themselves.

Many scholars from all around the world have expressed an interest in researching the impact of online marketing on student behaviour. Many academics performed studies all around the world to investigate the influence of digital communications on student admission choices (Kozinets, 1999; Mahajan \& Golahit, 2017; Mohammed \& Alkubise, 2012). Higher education marketers all around the world have poured a significant portion of their marketing expenditures into practically every available channel on the internet (Hemsley-Brown \& Oplatka, 2006; Sama, 2019). During the epidemic, the way candidates used to respond to web marketing and social media communications changed substantially (G. S. Bapat et al., n.d.). As a result, it has become crucial to research and examine how these applicants engage with and respond to all of the marketing that these higher education institutions in India are putting out online (Constantinides \& Stagno, 2011; Nagy et al., 2007).

\subsection{Literature Review}

The internet has evolved into a critical channel for delivering advertising messages to people (Norris, 1984). Over two decades ago, several experts predicted this tremendous transition. For example, in 1996, Ducoffe said that in the next 10-15 years, digital ads may have the strong effect on the advertising industry's potential (Ducoffe, 1996).

While offering a valuable source of information for customers, several concerns connected to the features of web ads must be considered. To put it another way, web advertising should have certain qualities to have the best influence on customers. According to one research, when data is communicated in a novel way, Internet users find it valuable. Alternatively, consumers' perceptions and interpretations of communications may be influenced by the content's reliability and informativeness (Abernethy, 1991).

The nature of engagement between marketers, advertising agencies, the media, and consumers has altered as a result of the internet. Internet Advertisement's revenues are rapidly increasing, indicating that Internet Ads are a viable alternative to conventional media. Because media features might impact consumer attitudes about advertising, the rapid proliferation of advertising to websites needs a better understanding of consumer attitudes toward Internet advertisements (Aydoğan et al., 2016).

Technology is assisting higher education marketers in efficiently communicating and reaching out to the target potential client by harnessing the power of all networked devices across the world. This demand is satisfied in new and innovative ways (Dwivedi et al., 2020; 
Guilbault, 2018; Thuy \& Thao, 2017). The development of technology has allowed for the exchange of information in order to call attention to the value (James-MacEachern \& Yun, 2017; Kusumavati, 2019).

\subsection{Theoretical Construction}

Chapman did a literature analysis on university admissions in 1981 to construct a model which would "assist college administrators responsible for recruitment policy in identifying the pressures and influences they must consider in developing institutional recruiting policy, as well as to aid continued research in the area of student college choice” (Chapman, 1981).

Fig. 1

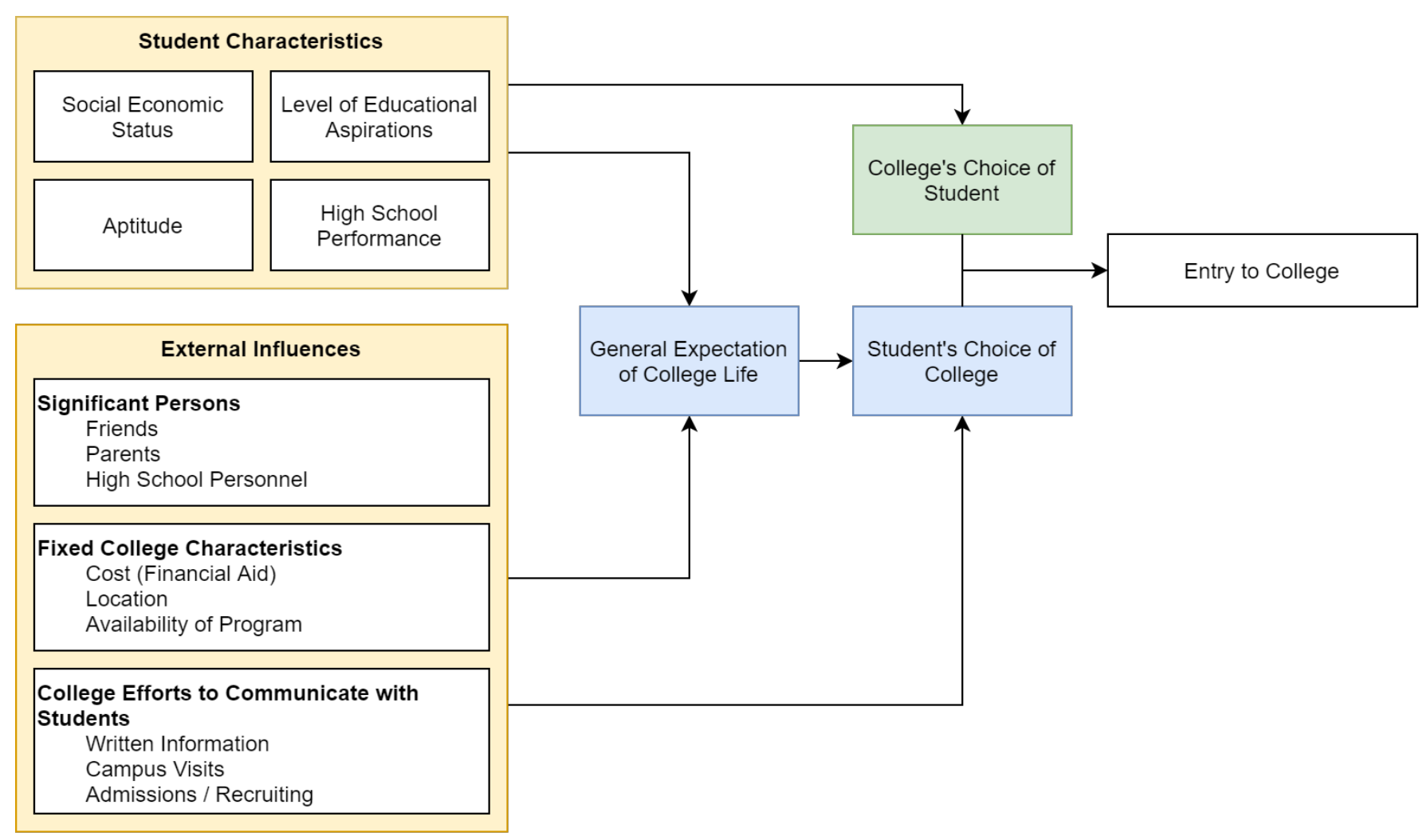

Chapman, D. W. (1981) 'A Model of Student College Choice', The Journal of Higher

Education, 52(5), p. 490. doi: 10.2307/1981837 
The printed materials that students see on campus and the marketers of higher education who engage in enrolment efforts, according to Chapman, have a considerable role in the selection development of students. Way a college or university seeks to interact with students is also quite important. (G. Bapat \& Chitnis, 2020).

This study's proposed model is shown below:

Fig. 2 Proposed Research Design

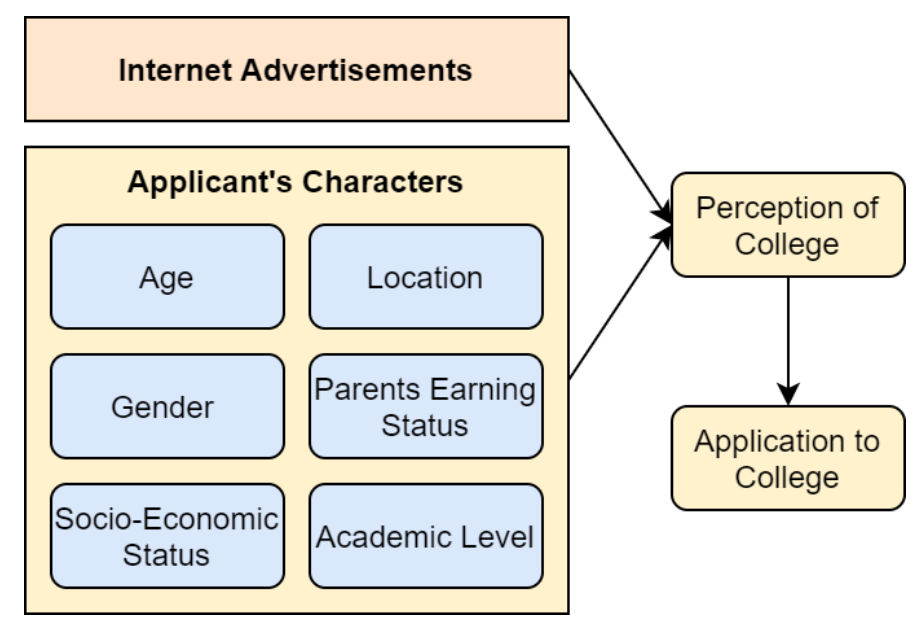

\section{Methods}

\subsection{Data and Sample}

A formal survey was disseminated using a convenience sampling method of 224 students. UG \& PG students from India's western region were polled. The survey was totally performed online. categorically candidate was allowed to submit only one response. Partial responses were excluded from the research due to their incompleteness, leaving 24 such responses. After everything was said and done, 200 replies were considered eligible for further research.

\subsection{Measures}

The survey had twelve distinct parameters. The entire survey was conducted using British English language. A seven-point Likert scale was used in the survey in which, level one represented strongly disagree and subsequently level seven represented strongly agreeing opinion of the respondent.

\subsection{Data Analysis}

SPSS software was used to analyse the data. The internal consistency of the scales was evaluated using Cronbach's alpha value. The instrument's reliability is tested using internal consistency reliability, which is measured using alpha coefficient reliability or Cronbach Alpha. The hypotheses were evaluated using the Chi-Square test.

\subsection{Research Context}

A significant amount of research has previously been done to determine the elements that are relevant and crucial for students to make admission-related decisions. The factors that influence students' decisions on which university to attend have been extensively examined (Le et al., 2020; Posselt et al., 2020; Vrontis et al., 2007). Unfortunately, research into the exact determinants was missing because many higher education institutions saw skyrocketing 
admissions before the pandemic reached the world, and as a result, education marketers were not too concerned in uncovering the elements relating to student selections (Aluwihare \& Manoshika, 2013; Watson, n.d.; Winn et al., 2014). Rather than recruitment, the emphasis in admissions was on selection (Dennis et al., 2016; Hindrawan, n.d.; Maringe, 2005). Unfortunately, no great theoretical inputs are available at this point of time to explorer the research in depth.

Students from diverse faculties, such as management, engineering, and commerce, were the researchers' target group. Researchers have been involved in the university's marketing decisions; nevertheless, from a research standpoint, it was discovered that there is little solid evidence available on the amount to which Internet advertisements influenced admissions for the academic year 2020-21.

\subsection{Testing}

Students from India who enrolled in a range of courses during the academic year 2020-21 were included in this study. International students are not included in this research. All Indian students from various private universities were intercepted utilising an internet channel for the sampling procedure. The research questionnaire was distributed to all pupils via their class teachers via an internet survey link.

This study was conducted entirely in English. In the fourth quarter of 2020, the research questionnaire was circulated among respondents. After rigorous study of the comments obtained, only 200 were judged eligible to be evaluated and incorporated for the research.

\subsection{Methodology}

The statistical analysis was carried out using SPSS version 25. The analysis of Qualitative Data Variables was expressed using frequency and percentages. The Chi-Square test was used to see whether there was a link between various demographic parameters and the study purpose, which was to see if there was a link between university advertisements on the internet. P-values of less than 0.05 were considered significant. 


\section{Results}

\begin{tabular}{|c|c|c|c|}
\hline & & $n$ & Percentage \\
\hline \multirow[t]{2}{*}{ Gender } & Male & 132 & $66.0 \%$ \\
\hline & Female & 68 & $34.0 \%$ \\
\hline \multirow{4}{*}{$\begin{array}{c}\text { Family's Financial } \\
\text { Condition }\end{array}$} & Upper Class & 4 & $2.0 \%$ \\
\hline & Upper Middle Class & 94 & $47.0 \%$ \\
\hline & Middle Class & 89 & $44.5 \%$ \\
\hline & Lower Middle Class & 13 & $6.5 \%$ \\
\hline \multirow[t]{2}{*}{ Original Residence } & Rural India & 24 & $12.0 \%$ \\
\hline & Urban India & 176 & $88.0 \%$ \\
\hline \multirow[t]{2}{*}{ Employment Status } & Both (Parents) Employeed & 52 & $26.0 \%$ \\
\hline & Single (Parent) Employeed & 148 & $74.0 \%$ \\
\hline \multirow[t]{3}{*}{ Academic Level } & Post Graduate & 6 & $3.0 \%$ \\
\hline & Under Graduate & 194 & $97.0 \%$ \\
\hline & Commerce & 31 & $15.5 \%$ \\
\hline \multirow[t]{3}{*}{ Faculty } & Engineering & 1 & $0.5 \%$ \\
\hline & Law & 1 & $0.5 \%$ \\
\hline & Management & 167 & $83.5 \%$ \\
\hline
\end{tabular}

Table 3-1 Profile of respondents

\begin{tabular}{cccc}
\hline $\begin{array}{c}\text { Have you experienced the } \\
\text { university advertisement you } \\
\text { are a student of }\end{array}$ & No & $n$ & Percentage \\
& Yes & 35 & $17.5 \%$ \\
\hline & Not Appealing & 2 & $82.5 \%$ \\
\hline
\end{tabular}




\begin{tabular}{cccc} 
How far the content of the & Somewhat Appealing & 6 & $3.6 \%$ \\
$\begin{array}{c}\text { Advertisement was effective } \\
\text { towards admission decision }\end{array}$ & Moderately Appealing & 38 & $23.0 \%$ \\
& Highly Appealing & 61 & $37.0 \%$ \\
& Extremely Appealing & 58 & $35.2 \%$ \\
\hline $\begin{array}{c}\text { How far the design of the } \\
\text { Advertisement was effective }\end{array}$ & Not Appealing & 3 & $1.8 \%$ \\
towards admission decision & Moderately Appealing & 40 & $3.0 \%$ \\
& Highly Appealing & 64 & $24.2 \%$ \\
& Extremely Appealing & 53 & $38.8 \%$
\end{tabular}

Table 3-2 Statistical Analysis of the impact of Internet Advertisements on Admissions Decision

\subsection{Hypothesis Testing}

\subsubsection{Hypothesis No 1}

\begin{tabular}{ccccc}
\hline $\begin{array}{c}\text { Age Group of the } \\
\text { Respondents }\end{array}$ & No & Yes Ads were relevant & Total & p-value \\
\hline$\leq 18$ & 15 & 116 & 131 & \\
$>18$ & 3 & 23 & 26 & 0.999 \\
\hline Total & 18 & 139 & 157 & \\
\hline
\end{tabular}

Table 3-3 Table indicating results of the Hypothesis Testing of Hypothesis No 1

The scientifically estimated p-value of 0.999 suggests that there is no link between the respondents' age group and their willingness to pay attention to university marketing on the internet.

\subsubsection{Hypothesis No 2}

\begin{tabular}{ccccc}
\hline Gender & \multicolumn{2}{l}{ Web Ads were relevant } & Total & p-value \\
& No & Yes & & \\
\hline $\boldsymbol{M}$ & 7 & 87 & 94 & \\
F & 11 & 52 & 63 & 0.073 \\
\cline { 1 - 3 } & 18 & 139 & 157 & \\
\hline
\end{tabular}

Table 3-4 Table indicating results of the Hypothesis Testing of Hypothesis No 2

The scientifically computed p-value of 0.073 reveals that there is no link between respondents' gender and their willingness to pay attention to online ads for colleges of interest. 


\subsubsection{Hypothesis No 3}

\begin{tabular}{ccccc}
\hline $\begin{array}{c}\text { Socio-Economic Status of } \\
\text { the family of the } \\
\text { respondents }\end{array}$ & No & Yes Ads were relevant & Total & p-value \\
\hline Lower Middle Class & 0 & 2 & 2 & \\
Middle Class & 10 & 60 & 70 & 0.754 \\
Upper Middle Class & 7 & 67 & 74 & \\
Upper Class & 1 & 10 & 11 & \\
\hline Total & 18 & 139 & 157 &
\end{tabular}

Table 3-5 Table indicating results of the Hypothesis Testing of Hypothesis No 3

The statistically computed p-value of 0.754 suggests that there is no link between the respondents' family's socioeconomic status and their willingness to pay attention to online marketing for colleges of interest.

As explained by Agarwal following are the Social Classifications reference was taken for the said study (Agarwal, 2008).

\begin{tabular}{lcc}
\hline Social class & \multicolumn{2}{c}{$\begin{array}{c}\text { Per capita monthly income } \\
\text { limits (Rs.) }\end{array}$} \\
\cline { 2 - 3 } & $\begin{array}{c}\text { Prasad's } \\
\text { classification } \\
\text { Classification for the } \\
\text { month of December 2004 }\end{array}$ & $\begin{array}{c}\text { Modified } \\
\text { proposed }\end{array}$ \\
\hline I. Upper high & 100 and above & 10000 and above \\
II. High & $50-99$ & $5000-9999$ \\
III. Upper middle & $30-49$ & $3000-4999$ \\
IV. Lower middle & $15-29$ & $1500-2999$ \\
V. Poor & Below 15 & $500-1499$ \\
VI. Very poor or & & \\
$\quad$ Below poverty & & Below 500 \\
line (BPL) & - &
\end{tabular}

Table 3-6 Agarwal A. Social classification: the need to update in the present scenario. Indian J Community Med [Internet]. 2008 Jan;33(1):50-1. Available from:

https://pubmed.ncbi.nlm.nih.gov/19966998

\subsubsection{Hypothesis No 4}

\begin{tabular}{ccccc}
\hline $\begin{array}{c}\text { Original Location of } \\
\text { the Respondents }\end{array}$ & No & Yes Ads were relevant & Total & p-value \\
\hline Rural India & 0 & 19 & 19 & \\
Urban India & 18 & 120 & 138 & 0.131 \\
\hline Total & 18 & 139 & 157 & \\
\hline
\end{tabular}


Table 3-7 Table indicating results of the Hypothesis Testing of Hypothesis No 4

The scientifically computed p-value of 0.131 suggests that there is no link between respondents' original location and their willingness to pay attention to online marketing for colleges of interest.

\subsubsection{Hypothesis No 5}

\begin{tabular}{ccccc}
\hline $\begin{array}{c}\text { Earning Status of the Parents of } \\
\text { the respondents }\end{array}$ & \multicolumn{2}{c}{ Web Ads were relevant } & Total & p-value \\
\hline Both Parent Earning & 2 & Yes & 38 & 40 \\
Single Parent Earning & 16 & 101 & 117 & 0.163 \\
\hline Total & 18 & 139 & 157 & \\
\hline
\end{tabular}

Table 3-8 Table indicating results of the Hypothesis Testing of Hypothesis No 5

The scientifically computed p-value of 0.040 reveals that there is a link between the respondents' Earning Status and their willingness to pay attention to online marketing for institutions of their choice.

\subsubsection{Hypothesis No 6}

\begin{tabular}{ccccc}
\hline $\begin{array}{c}\text { Academic Level of the } \\
\text { respondents }\end{array}$ & No & Yes Ads were relevant & Total & p-value \\
\hline $\begin{array}{c}\text { Post Graduate } \\
\text { Under Graduate }\end{array}$ & 1 & 0 & 1 & \\
\hline Total & 18 & 139 & 156 & 0.115 \\
\hline
\end{tabular}

Table 3-9 Table indicating results of the Hypothesis Testing of Hypothesis No 6

The statistically estimated p-value of 0.115 suggests that there is no correlation between the respondents' Academic Level and their proclivity to pay attention to online ads for colleges of interest.

\subsubsection{Hypothesis No 7}

\begin{tabular}{ccccc}
\hline $\begin{array}{c}\text { Academic Stream of the } \\
\text { respondents }\end{array}$ & No & Yes Ads were relevant & Total & p-value \\
\hline Commerce & 1 & 26 & 27 & \\
Engineering & 0 & 1 & 1 & 0.295 \\
Management & 17 & 112 & 129 & \\
\hline Total & 18 & 139 & 157 & \\
\hline
\end{tabular}

Table 3-10 Table indicating results of the Hypothesis Testing of Hypothesis No 7 
The statistically estimated p-value of 0.295 suggests that there is no correlation between the respondents' Academic Level and their proclivity to pay attention to online ads for colleges of interest.

\section{Conclusion}

Researchers discovered that the age of the student had no bearing on the efficiency of Internet ads for university enrollment after testing all seven hypotheses. It was observed that prospective candidates no matter which academic level they are from, they were equally interested in web ads. Hence it shows that higher education marketers must note that it would not matter which academic level they are targeting at the importance given to the web ads should be equal.

This study also uncovered a fact that even if a student belongs to a weaker or financially stronger section, the impact of web ads on the student and the parents was equal. Also, the gender of the candidate had no relationship with the interests that they may have with the higher education institutions web ads.

It was interesting to note that even if the candidate belongs to rural India or urban India the effect that web ads had on such candidates was at par.

As previously indicated, the students' age group, which includes whether they are pursuing a postgraduate or undergraduate degree, does not influence the decision to respond to advertising. Applicants from three distinct academic streams were studied, namely Commerce, Engineering, and Management, and candidates from these knowledge streams showed a comparable interest in online ads.

These findings suggest that higher education marketers in India should be very cautious when developing their online marketing communications, as all cross-sections of candidates are equally interested in internet ads. This demonstrates that online ads would influence all stages of applications, making it one of the most successful communication platforms for higher education marketers in India.

\subsection{Implications for Asian Business}

In current history, Asia's unprecedented growth in influence and power has become a constant presence in financial and trade analyses across the world. The territory's economic and geopolitical importance in the globe has undoubtedly become one of the most important drivers of global marketplaces in a variety of sectors and industries, particularly research, technology, and innovation. Tech hotspots like Singapore and Hong Kong, dubbed the "New Silicon Valley," draw significant investments from the United States and Europe, and an increasing trend of established companies, as well as start-ups, opt to establish operations in these extremely dynamic markets.

The region's remarkable increase in the higher education sector has aided its expansion. Asian institutions increasingly challenged the West's position as the worldwide market leader in terms of research, innovation, and educational superiority. China, Singapore, Hong Kong, Japan, and South Korea have invested significantly in research-focused universities and research institutes, and their initiatives are now yielding dividends. Asia was reflected in the top 50 universities in the most recent University Rankings by 11 universities. In the Asian area, the university environment is diversified, with some universities having extensive histories. The size and emphasis of universities in Asia also vary. 
The idea of integrating private investment into Indian higher education was initially envisioned in a study published in 2008 by the Planning Commission of India's National Knowledge Commission (Knowledge Commission, n.d.). After private funding was available in India, two types of universities arose: Deemed to be Universities and State Private Universities. The government's decision to allow private participation in India's university system was well received by private investors. As a result, India's state-owned private universities have grown dramatically. The expansion began in the second part of the 1990s, and by 2018, India had 216 Deemed to be Universities, up from 33 in 1990. Almost all of the institutions in this category were founded using private funds.

A favourable global environment, particularly for India, in the post-pandemic age, has yet to show the delayed effects of India's liberal policy in growth figures. India is projected to exceed several Asian countries in terms of growth. India is expected to expand at a rate of around 12.8 per cent (Indian Economy: India Likely to Outperform Asian Economies, Clock 12.8\% Growth in 2021: Nomura - The Economic Times, n.d.). Highly skilled workers, which is a natural product of universities, would propel this progress. Marketing communications are critical to the success of universities. As a result, studies like these are intended to contribute to a better knowledge of consumer behaviour, namely that of students and parents, to better grasp their decision-making process.

\subsection{Limitations}

The research has a sample selection constraint. The students that were sampled were those who planned to apply to higher education institutions in the city of Pune, India. As a result of this restriction, the findings' generalizability may not apply to all internet users in India. The researchers did not analyse respondents for specific online advertising platforms, which is the second major drawback of this study.

\section{References:}

Abernethy, A. M. (1991). Differences between advertising and program exposure for car radio listening. Journal of Advertising Research, 31(2), 33-42.

Agarwal, A. (2008). Social classification: the need to update in the present scenario. Indian Journal of Community Medicine : Official Publication of Indian Association of Preventive \& Social Medicine, 33(1), 50-51. https://doi.org/10.4103/0970-0218.39245

Aluwihare, P. S. D., \& Manoshika, R. (2013). Addressing the issues of low student enrollment - The case of the Kandy Regional Centre of the Open University of Sri Lanka. Asian Association of Open Universities Journal, 8(1), 103-115. https://doi.org/10.1108/aaouj-08-012013-b010

Aydoğan, S., Aktan, M., Aysuna, C., Aydogan, S., \& Aysuna, C. (2016). Web Advertising Value and Students' Attitude Towards Web Advertising. European Journal of Business and Management, 8(9), 86-97. https://www.researchgate.net/publication/311767855

Bapat, G., \& Chitnis, R. (2020). To study the effectiveness of university website for university admissions in COVID-19 crisis. December, 12.

Bapat, G., Ravikumar, C., \& Shrivallabh, S. (2021). An exploratory study to identify the important factor of the university website for admissions during covid-19 crisis. Journal of Engineering Education Transformations, 35(1), 116-120. https://doi.org/10.16920/jeet/2021/v35i1/155961

Bapat, G. S., Gankar, S. S., Professor, A., \& of Management, F. (n.d.). How students make 
choice of Universities: Understanding students decision making with reference to Digital Media. In Bi-Monthly, Peer-Reviewed, Refereed, Indexed Journal Impact Factor (Issue 2). Retrieved December 31, 2019, from http://www.nacacnet.org/

Bapat, G. S., Mahale, P., Kumar, A., \& Srinivasan, R. (2021). The Impact of Television Advertisements on Student Decision-Making Process for College Admission: An exploratory study in India. Asia Pacific Journal of Health Management, 16(4), 266-273. https://doi.org/10.24083/apjhm.v16i4.1299

Chapman, D. W. (1981). A Model of Student College Choice. The Journal of Higher Education, 52(5), 490. https://doi.org/10.2307/1981837

Constantinides, E., \& Stagno, M. C. Z. (2011). Potential of the social media as instruments of higher education marketing: A segmentation study. Journal of Marketing for Higher Education, 21(1), 7-24. https://doi.org/10.1080/08841241.2011.573593

Coyne, C., Ballard, J. D., \& Blader, I. J. (2020). Recommendations for future university pandemic responses: What the first COVID-19 shutdown taught us. In PLoS Biology (Vol. 18, Issue 8, p. e3000889). https://doi.org/10.1371/journal.pbio.3000889

Dennis, C., Papagiannidis, S., Alamanos, E., \& Bourlakis, M. (2016). The role of brand attachment strength in higher education. Journal of Business Research, 69(8), 3049-3057. https://doi.org/10.1016/j.jbusres.2016.01.020

Ducoffe, R. H. (1996). Advertising value and advertising on the Web. Journal of Advertising Research, 36(5), 21-35.

Duffett, R. G. (2017). Influence of social media marketing communications on young consumers' attitudes. Young Consumers, 18(1), 19-39. https://doi.org/10.1108/YC-07-201600622

Dwivedi, Y. K., Hughes, D. L., Coombs, C., Constantiou, I., Duan, Y., Edwards, J. S., Gupta, B., Lal, B., Misra, S., Prashant, P., Raman, R., Rana, N. P., Sharma, S. K., \& Upadhyay, N. (2020). Impact of COVID-19 pandemic on information management research and practice: Transforming education, work and life. International Journal of Information Management, 55(July), 102211. https://doi.org/https://doi.org/10.1016/j.ijinfomgt.2020.102211

Gottlieb, U. R., \& Beatson, A. (2018). High on emotion! perceived value: influencing decisionmaking processes at international student recruitment trade shows. Journal of Marketing for Higher Education, 28(2), 282-297. https://doi.org/10.1080/08841241.2018.1476430

Guilbault, M. (2018). Students as customers in higher education: The (controversial) debate needs to end. Journal of Retailing and Consumer Services, 40, 295-298. https://doi.org/10.1016/j.jretconser.2017.03.006

Hemsley-Brown, J., \& Oplatka, I. (2006). Universities in a competitive global marketplace: A systematic review of the literature on higher education marketing. International Journal of Public Sector Management, 19(4), 316-338. https://doi.org/10.1108/09513550610669176

Herold, K., Sipilä, J., Tarkiainen, A., \& Sundqvist, S. (2017). How service values influence the processing of word-of-mouth in the evaluation of credence beliefs. Journal of Marketing for Higher Education. https://doi.org/10.1080/08841241.2016.1213347

Hindrawan, M. J. International Student Recruitment, Admissions, and Enrollment Management: A Case Study of University at Buffalo, The State University of New York University at Buffalo, The State University of New York. Retrieved February 2, 2019, from https://www.meiji.ac.jp/cip/riie/6t5h7p00000anicx-att/a1331616741889.pdf 
Humlum, M. K., Kristoffersen, J. H. G., \& Vejlin, R. (2017). College admissions decisions, educational outcomes, and family formation. Labour Economics, 48, 215-230. https://doi.org/10.1016/j.labeco.2017.08.008

indian economy: India likely to outperform Asian economies, clock 12.8\% growth in 2021: Nomura - The Economic Times. (n.d.). Retrieved July 12, 2021, from https://economictimes.indiatimes.com/markets/expert-view/nomura-sees-india-outperformrest-of-asia-notch-up-12-8-growth-in-2021/articleshow/80329180.cms?from=mdr

James-MacEachern, M., \& Yun, D. (2017). Exploring factors influencing international students' decision to choose a higher education institution: A comparison between Chinese and other students. International Journal of Educational Management, 31(3), 343-363. https://doi.org/10.1108/IJEM-11-2015-0158

Jan, M. T., \& Ammari, D. (2016). Advertising online by educational institutions and students' reaction: a study of Malaysian Universities. Journal of Marketing for Higher Education, 26(2), 168-180. https://doi.org/10.1080/08841241.2016.1245232

Joshi, A., Amadi, C., Alam, A., Krudysz, M. A., \& Hernandez, G. (2017). Using Data to Inform Decision Making in Recruitment of Prospective Public Health Students. Research in Higher Education Journal, 32. http://www.aabri.com/copyright.html

Keegan, B. J., \& Rowley, J. (2017). Evaluation and decision making in social media marketing. Management Decision, 55(1), 15-31. https://doi.org/10.1108/MD-10-2015-0450

Knowledge Commission, N. (n.d.). Towards a knowledge society. Retrieved June 1, 2020, from www.knowledgecommission.gov.in

Kozinets, R. V. (1999). E-tribalized marketing?: The strategic implications of virtual communities of consumption. European Management Journal, 17(3), 252-264. https://doi.org/10.1016/S0263-2373(99)00004-3

Kumar, A., Syed, A. A., \& Pandey, A. (2021). Adoption of online resources to improve the marketing performance of SMES. Asia Pacific Journal of Health Management. https://doi.org/10.3316/INFORMIT.081159555237037

Kusumavati, A. (2019). Impact of Digital Marketing on Student Decision-Making Process of Higher Education Institution: A Case of Indonesia. Journal of E-Learning and Higher Education, July, 1-11. https://doi.org/10.5171/2019.267057

Le, T. D., Robinson, L. J., \& Dobele, A. R. (2020). Understanding high school students use of choice factors and word-of-mouth information sources in university selection. Studies in Higher Education, 45(4), 808-818. https://doi.org/10.1080/03075079.2018.1564259

Mahajan, P. T., \& Golahit, S. B. (2017). Engineering a Woman: Marketing Opportunities and Challenges in India. American Journal of Management Science and Engineering, 2(1), 11-22. https://doi.org/10.11648/j.ajmse.20170201.12

Maringe, F. (2005). Interrogating the crisis in higher education marketing: The CORD model. International Journal of Educational Management, 19(7), 564-578. https://doi.org/10.1108/09513540510625608

Mittal, B. (2017). Facing the Shelf: Four Consumer Decision-making Styles. Journal of International Consumer Marketing, 303-318. https://doi.org/10.1080/08961530.2017.1318732

Mohammed, A. B., \& Alkubise, M. (2012). How do Online Advertisements Affects Consumer Purchasing Intention: Empirical Evidence from a Developing Country. European Journal of 
Business and Management, 208-218. http://www.iiste.org/Journals/index.php/EJBM/article/view/1829/1782

Nagy, J., Demiray, U., \& Yilmaz, A. (2007). Strategies For The Marketing Of Higher Education With Comparative Contextual References Between Australia And Turkey. Turkish Online Journal of Distance Education, 8(2), 157-173. https://doi.org/10.17718/tojde.81829

Nicosia, F. M. (role)aut. (1966). Consumer decision processes : marketing and advertising implications. Englewood Cliffs (N.J.): Prentice Hall. http://lib.ugent.be/catalog/rug01:001231927

Norris, V. P. (1984). The Economic Effects of Advertising: A Review of the Literature. Current Issues and Research in Advertising, 7(2), 39-134. https://doi.org/10.1080/01633392.1984.10505366

Posselt, J., Hernandez, T. E., Villarreal, C. D., Rodgers, A. J., \& Irwin, L. N. (2020). Evaluation and Decision Making in Higher Education (pp. 1-63). https://doi.org/10.1007/978-3-03011743-6_8-1

Sama, R. (2019). Impact of Media Advertisements on Consumer Behaviour. Journal of Creative Communications, 14(1), 54-68. https://doi.org/10.1177/0973258618822624

Schlosser, A. E., Shavitt, S., \& Kanfer, A. (1999). Survey of Internet users' attitudes toward Internet advertising. Journal of Interactive Marketing, 13(3), 34-54. https://doi.org/10.1002/(SICI)1520-6653(199922)13:3<34::AID-DIR3>3.0.CO;2-R

Taken Smith, K. (2012). Longitudinal study of digital marketing strategies targeting Millennials. Journal of Consumer Marketing, 29(2), 86-92. https://doi.org/10.1108/07363761211206339

Thuy, V. T. N., \& Thao, H. D. P. (2017). Impact of students' experiences on brand image perception: the case of Vietnamese higher education. International Review on Public and Nonprofit Marketing, 14(2), 217-251. https://doi.org/10.1007/s12208-016-0171-x

Usher, K., Bhullar, N., \& Jackson, D. (2020). Life in the pandemic: Social isolation and mental health. Journal of Clinical Nursing, 29(15-16), 2756-2757. https://doi.org/10.1111/jocn.15290

Vrontis, D., Thrassou, A., \& Melanthiou, Y. (2007). A contemporary higher education studentchoice model for developed countries. Journal of Business Research, 60(9), 979-989. https://doi.org/10.1016/j.jbusres.2007.01.023

Watson, B. L. (n.d.). A descriptive study of enrollment marketing strategies for four -year public colleges and universities. Retrieved March 26, 2019, from https://digitalscholarship.unlv.edu/rtds/3108

Winn, M., Leach, L., Erwin, S., \& Benedict, L. (2014). Factors Affecting Graduate Educational Leadership Program Selection. Administrative Issues Journal: Education, Practice, and Research, 4(1). https://doi.org/10.5929/2014.4.1.4 